\title{
MANAGING SPENT NUCLEAR FUEL FROM NON- PROLIFERATION, SECURITY AND ENVIRONMENTAL PERSPECTIVES
}

\author{
JOR-SHAN CHOI \\ Global Nuclear Education \& Research Initiative \\ Tokyo University, 7-3-1 Hongo, Bunkyo-ku, Tokyo, 113-8656, Japan \\ *Corresponding author. E-mail : choi@nuclear.jp
}

Received April 28, 2010

The growth in global energy demand and the increased recognition of the impacts of carbon dioxide emissions from fossil fuel plants have aroused a renewed interest on nuclear energy. Many countries are looking afresh at building more nuclear power stations to deal with the twin problems of global warming and the need for more generating capacity. Many in the nuclear community are also anticipating a significant growth of new nuclear generation in the coming decades. If there is a nuclear renaissance, will the expansion of nuclear power be compatible with global non-proliferation and security? or will it add to the environmental burden from the large inventory of spent nuclear fuel already produced in existing nuclear power reactors? We learn from past peaceful nuclear activities that significant concerns associated with nuclear proliferation and spent-fuel management have resulted in a decrease in public acceptance for nuclear power in many countries. The terrorist attack in the United States (US) on September 11, 2001 also raised concern for security and worry that nuclear materials may fall into the wrong hands. As we increase the use of nuclear power, we must simultaneously reduce the proliferation, security and environmental risks in managing spent-fuel below where they are today.

KEYWORDS : Spent Nuclear Fuel, Non-proliferation, Security, Environmental Burden, "Cradle-to-grave” Fuel Cycle Services, Underground Spent Fuel Storage, Advanced Partitioning, Deep Bolehole Disposal

\section{INTRODUCTION}

Nuclear energy currently accounts for about $15 \%$ of the global electricity generation. It delivers significant amounts of very low carbon base-load electricity at stable costs over time. Despite its contributions and great potential, the expansion of nuclear energy stands at a crossroad, facing significant challenges in nuclear proliferation, security, and spent-fuel/waste management. These are intractable techno-institutional issues hindering the expanded use of nuclear energy for peaceful purposes.

The world's 439 nuclear power reactors operating in 30 countries today generate spent nuclear fuel (SNF) that is mostly stored on-site in wet storage pools. The total SNF inventory, as shown in figure 1 is estimated to reach 250,000 tons as of 2010[1]. Most of the SNF are produced and stored in the US (about a quarter of the total) and several countries with major nuclear power programs (the top 10 countries hold about $87 \%$ of the total). As this inventory will continue to grow and with pools filling up despite re-racking, nuclear utilities have turned increasingly to dry storage to alleviate their SNF storage problem.

The current US SNF inventory of approximately
64,000 tons has exceeded the statutory capacity of the now-cancelled repository at Yucca Mountain (YM). The US Department of Energy (DOE) withdrew the YM license application from NRC and formed a Blue Ribbon Commission in 2010 to study the spent fuel and waste problems [2,3]. Meanwhile, the public confidence in nuclear energy has been tarnished by the debate on the long-term disposal of radioactive wastes. Such skepticism regarding a solution to spent fuel management could undermine the credibility, if not the viability, of nuclear power.

The withdrawal of the YM license application not only slow the spent fuel management progress in the US, but also have significant ramification to other spent fuel management policies and programs around the world, notably in East Asia. For instance, Taiwan is now facing a critical decision to move its spent fuel from the pool at the Chinshan Power Station to on-site dry cask storage or to shut the reactor down because of the lack of a full-core reserve in the spent fuel pool [4]; South Korea will face a similar situation in its Kori Power Station in around 2016 [5]; Japan may have to consider on-site dry cask storage for many of its power plants due to the delay in its reprocessing operation at Rokkasho-mura [6]. 


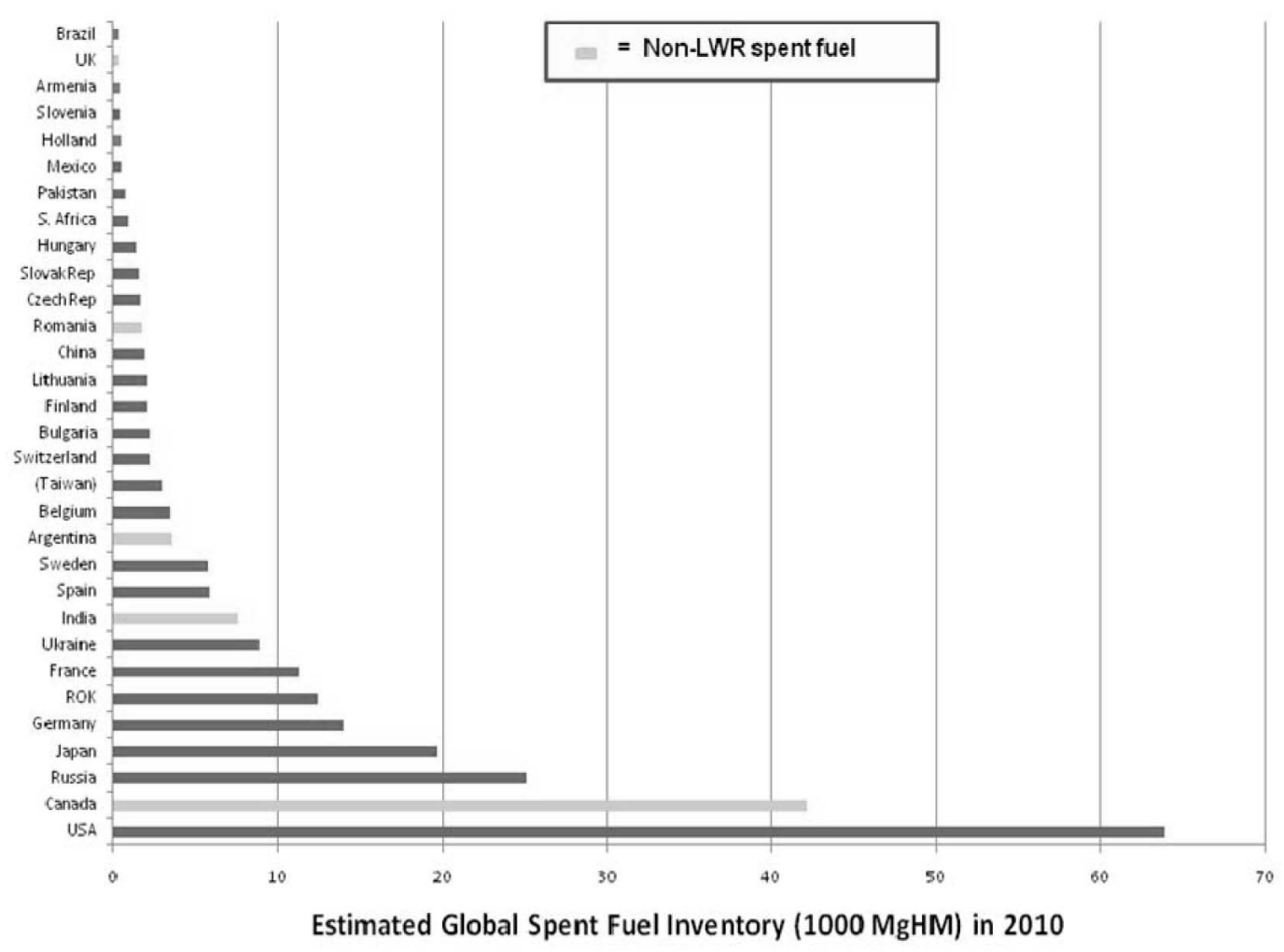

Fig. 1. Global Spent Fuel Inventory in 2010

As the amount of the spent fuel from existing and new nuclear power plants will increase year after year, the capacity of SNF storage pools at the reactor sites would be filled, dry storage casks, either vertically or horizontally emplaced would be the mode of operation. Following the terrorist attacks in the U.S. on 11 September, 2001 , there is a specific concern for physical protection of nuclear installations against the threats from strikes with a missile, a projectile, or an airplane. Surface dry cask facilities storing spent fuel could be targets for such threats. Putting the storage casks underground would reduce their visibility from plant site boundary and from aerial flight routes, and could possibly reduce or eliminate the potentials of such threats.

The global expansion of nuclear power would undoubtedly include countries located in less-stable regions of the world, notably those in the Middle East and North Africa [7]. If these countries operate nuclear reactors and produce SNF, the presence of plutonium $(\mathrm{Pu})$, albeit imbedded in the $\mathrm{SNF}$, increases the proliferation risk if the $\mathrm{Pu}$ is clandestinely recovered in fuel reprocessing, or if the country decides to "break out" of its "non-proliferation obligation" and recover the $\mathrm{Pu}$ for a weapons program. Furthermore, plutonium poses a security risk if it falls into the hands of terrorists or other rogue actors.

A return to substantial new nuclear power must satisfy a combination of new technology; coordinated, international fuel cycle services; and a set of system-wide objectives must be in place which would simultaneously provide the option to meet future energy demands while reducing the proliferation, security and environmental risks in managing spent-fuel below where they are today.

\section{REDUCING THE PROLIFERATION RISKS}

To stop the "onward proliferation" and to prevent nuclear weapons, materials or capabilities from falling into the wrong hands, several proposals were made to limit enrichment and reprocessing operations either under multinational control; or to states that already have full scale functioning plants; or in a regional fuel cycle center [8-10]. The IAEA has promoted the multilateral mechanism and there are currently 12 multilateral approach proposals on reliable fuel supply [11]. These proposals aim to provide incentives to countries interested in building nuclear power plants for energy security and combating climate change.

While the focus of the multilateral mechanisms is on the front-end of reliable fuel supply, the challenges remain in the back-end: What can be done with the growing stocks of spent fuel in existing nuclear programs? And how can the proliferation and security concerns be reduced when spent fuels are generated in newcomer countries located in less stable regions of the world? It has been pointed out 
that the arrangements that would provide assured return of spent nuclear fuel could provide a powerful incentive for countries to rely on an international nuclear fuel supply [12]. However, for many countries, the political barriers to taking other countries' spent nuclear fuel or nuclear waste are substantial.

There is currently a trend that utility companies would prefer the supply of fabricated fuel in a package deal. Reactor vendors, fuel fabricators, and big uranium suppliers are forming partnerships or commercial consortia to offer fuel-cycle service to existing and newcomer nuclear countries. If such service could include the reliable supply of fabricated fuel and the timely removal of spent fuel for interim storage at regional locations, a "cradle-to-grave" scheme can be realized. The crux of such service is the provision of interim storage of spent nuclear fuel (SNF). Under certain cooperative arrangements, spent fuel discharged in the back-end can be removed for interim storage at locations operated by nuclear consortia and supported by their respective national governments. Such arrangements, together with packaged front-end fuelsupply deal including conversion, enrichment, and fuel fabrication, can provide a "cradle-to-grave" nuclear fuelcycle service to countries interested in producing electricity for their citizens.

This "cradle-to-grave" fuel-cycle service could be attractive to countries with small nuclear power programs and small amounts of spent fuel (about 2/3 of the countries currently operating civil reactors), and densely-populated countries that have limited space to develop their own repositories for spent fuel and radioactive wastes. The "cradle-to-grave" service would also be an attractive option for new and emerging nuclear countries as they would have the assurance of reliable fresh fuel supply and timely spent fuel removal. These countries can benefit from nuclear energy without the burdens of proliferation concerns and SNF management, much like a country can provide air transportation to its citizens by operating airlines without the large investment in aircraft manufacturing.

However, not all countries can or are willing to provide back-end spent fuel take-back services. As it stands, nuclear weapons states operate more than $50 \%$ of the world's nuclear electricity generation capacity, and hold more than half of the global spent fuel and radioactive waste inventories. Perhaps, they could provide spent-fuel storage and waste disposal services to other countries within their region. For instance, the former Soviet Union took spent fuel back from the Soviet-designed reactors located in Eastern Europe and Finland. Currently, Russia accepts spent VVER fuel from Commonwealth Independent States (CISs) for a fee and on a case-by case basis. Russia also offers a SNF take-back service to Iran. The US takes back research reactor spent fuel from other countries on grounds of non-proliferation. Major uranium-producing countries such as Canada, Australia, Kazakhstan and others can help in providing interim storage of spent fuel from other countries. The return of spent fuel to the uranium producing countries for storage could enhance global security and non-proliferation, and simultaneously benefit their respective uranium-supply businesses.

The importance of the SNF take-back or take-away service is to relieve the burden of proliferation, security, and SNF management for countries/utilities operating nuclear reactors. The service is by no means a restriction to a country's own fuel cycle development. The service, if it can be provided, is only an option aimed at improving nonproliferation and security, and SNF management. If a country decides to develop its own enrichment and reprocessing, it should prepare to deal with the proliferation, security and wastes issues in a manner conforming to international regulations.

\section{REDUCING THE SECURITY RISKS}

The USNRC has determined that dry-cask storage of spent fuel at reactor sites is safe for at least 100 years. Putting the storage casks underground or in shielded shelters would reduce their visibility from plant site boundary and from aerial flight routes, and could reduce or eliminate the potentials of terrorist threats.

If canisters were stored underground, it would provide more flexibility in siting the storage facilities. The storage efficiency would be improved as spacing between storage units could be minimized as compared to the larger spacing required between units stored above-ground to accommodate the potential for knocking-over during seismic events or terrorist attacks. Also, the underground facilities would have the advantage that the surrounding earth could help in radiation shielding and physical protection albeit that the effectiveness of decay heat removal must be assured. In underground storage, the decay heat would have to be transferred by convection around the storage cavity and by conduction through the surrounding earth.

There were some issues concerning the licensing aspects of the underground cask storage. The USNRC issued only one site-specific license so far for below grade storage of spent fuel at Humboldt Bay Power Plant site [13]. The experience indicated that measures against leakage of canisters for spent fuel and seismic design method of underground vault would have to be evaluated on a sitespecific basis.

There are several underground storage concepts which have been in development, mostly based on subsurface application of heat conduction or convection. Even though they have not been used on commercial scale yet, changing circumstance in the spent fuel management area may make alternative concepts attractive provided they become competitive in the new criteria, such as the security issues which have become a higher priority throughout the world. These underground storage concepts are:

- Underground vertical-ventilated-module (VVM) storage 
concept $[13,14]$

- Drywell [15]

- Twin tunnel storage concept [16,17]

- Sheltered Storage [18,19]

The advantages of underground cask storage are: (1) not visible from plant site boundary or aerial flight routes; (2) reducing the potential for a strike with a missile, projectile, or an airplane; (3) minimizing the spacing between storage units, as compared to larger spacing between units on above-ground storage; and (4) more flexible in siting storage facilities.

The concept of internationalization of long-term underground interim storage may offer additional advantages. Country has a suitable host rock formation and is willing to open for the interim storage of spent fuel could offer such a facility to store its own spent fuel and those from other countries. Site selection would then be subject to competition, offering additional potential for reducing storage costs.

The challenges for underground cask storage are: (1) the effectiveness of decay heat removal must be assured; (2) the handling of and storing casks underground or below-grade must not create unwanted complication, such as flooding of storage cavity, tilting of storage cask, etc., (3) the seismic design of underground storage must be adequate; and (4) the costs for underground storage must be compatible to that of above-ground storage.

\section{REDUCING ENVIRONMENTAL RISKS}

To minimize the environmental risk and the repository need, the spent fuel waste volume has to be reduced. Here, we envision an advanced concept involving spent fuel reprocessing and separation of selected radio-nuclides. For instance, the uranium which accounts for $95.6 \mathrm{wt} \%$ of SNF can be separated and either reused as fuel or disposed of in the original uranium mines. The TRUs (about $1 \mathrm{wt} \%$ ) can be recovered, mixed with depleted or natural uranium and fabricated into fuel for fast reactors. The highly-radioactive and heat-producing strontium $(\mathrm{Sr})$ and cesium (Cs), about $0.3 \mathrm{wt} \%$ can be separated and stowed away in a monitored surface facility until they decay away (in about 300 years for ${ }^{90} \mathrm{Sc}$ and ${ }^{137} \mathrm{Cs}$ ). They can also be encapsulated and disposed of in deep boreholes. The deep borehole concept was previously studied for disposition of weapons plutonium [20]. It needs to be further developed and can be suitable for disposing the long-lived isotope, such as ${ }^{135} \mathrm{Cs}$. Other long-lived radionuclides (e.g., ${ }^{129} \mathrm{I},{ }^{99} \mathrm{Tc},{ }^{237} \mathrm{~Np}$ ), about 0.1 wt $\%$ can also be separated, encapsulated and disposed of in deep bore holes. The remaining $3 \mathrm{wt} \%$ of the SNF is the stable shortlived fission-product which presents no major disposal concern and can be disposed of as low-level wastes (LLW). Table 1 summarizes the contents of SNF and lists the possible disposition methods.

The removal of the heat-generating (primarily ${ }^{90} \mathrm{Sr}$ and ${ }^{137} \mathrm{Cs}$ ) and the long-lived (notably ${ }^{129} \mathrm{I},{ }^{99} \mathrm{Tc},{ }^{237} \mathrm{~Np}$ ) radionuclides, and subsequently the encapsulation and disposal of these radio-nuclides in deep boreholes can significantly reduce the long-term environmental burden posed by the SNF. The remaining ingredients in the SNF (mainly, TRUs, uranium, and stable short-lived fission products) can be transmuted as fuel in fast reactors, directly disposed of in original uranium mines, and as LLW, respectively. If the deep borehole concept can be demonstrated to be technically and economically viable, the need for geologic repositories can be significantly minimized.

The concept requires cost-effective reprocessing technologies. At present, the PUREX reprocessing process is not economical in several countries (notably, the US). Other innovative and advanced separation technologies,

Table 1. Contents of a Spent Nuclear Fuel and Possible Disposition Methods

\begin{tabular}{c|l|c|l}
\hline Item & \multicolumn{1}{|c|}{ Content } & Wt\% & \multicolumn{1}{c}{ Possible Disposition Methods } \\
\hline 1 & Uranium & 95.6 & $\begin{array}{l}\text { Recycled and used in reactors or disposed } \\
\text { of in original uranium mines }\end{array}$ \\
\hline 2 & Stable short-lived fission products & 3.0 & $\begin{array}{l}\text { Pose no major disposal concern, disposed of } \\
\text { as LLW }\end{array}$ \\
\hline 3 & TRU & 1.0 & Recycled and used in reactors \\
\hline 4 & $\begin{array}{l}\text { Radioactive and heat producing fission } \\
\text { products, e.g., cesium }(\mathrm{Cs}) \text { and strontium }(\mathrm{Sc})\end{array}$ & 0.3 & $\begin{array}{l}\text { Separated and decay away in about } 300 \text { years, } \\
\text { or disposed of in a deep boreholes with } \\
\text { long-lived fission products }\left({ }^{135} \mathrm{Cs} \text { and those }\right. \\
\text { in item 5) }\end{array}$ \\
\hline 5 & Long-lived radio-nuclides, e.g., ${ }^{129} \mathrm{I},{ }^{99} \mathrm{Tc},{ }^{237} \mathrm{~Np}$ & 0.1 & Separated and disposed of in deep boreholes \\
\hline
\end{tabular}


such as the dry or pyro-chemical processes can be developed and deployed to defray the high reprocessing costs. The deep-borehole concept was previously studied for disposition of weapons plutonium, and more R\&D may be needed to assess the concept's viability as well as its costs.

\section{CONCLUSION}

There is little doubt that nuclear energy will remain an important part of the global energy mix. The growing world population and the desire to raise the standard of living in the developing world will keep the demand for energy strong for the foreseeable future. The recognition of the environmental impact of the carbon cycle has prompted countries to diversify their energy sources. Nuclear energy is a proven technology that can provide a large-scale electricity generation base without emitting greenhouse gases and further damaging the global environment. Currently, nuclear power is helping the transportation sector by producing electricity to support the hybrid and electric car industry. In the future, nuclear energy can also help offset transportation emissions through the production of hydrogen and the support of a hydrogen fuel cycle.

Despite its current contributions to the energy supply, nuclear energy will not be able to fulfill its potential unless the issues associated with proliferation, security, and spent fuel/radioactive waste management are resolved. To reduce the proliferation risks, especially for newcomer countries located in the less-stable regions, interim SNF storage (for 50 years) should be provided under certain cooperative arrangements. Such provisions would allow for "cradle-to-grave" fuel cycle services supplying reliable fresh fuel, taking-back/taking away spent fuel, and supporting an expansion of nuclear power that is economically competitive, meets the applicable international safety standards, and complies with international safeguards and security requirements.

To reduce the terrorist threats posed on the dry-cask storage, especially after the terrorist attacks in the U.S. on 11 September, 2001, storage casks can be placed underground or inside a sheltered facility to reduce their visibility from plant site boundary and from aerial flight routes. The underground storage can also provide more flexibility in siting the storage facility..

Advanced technologies should be employed to reduce the long-term environmental risks posed by the accumulation of spent fuel and radioactive wastes. These technologies can be used to reduce the separated plutonium inventories and spent fuel waste volume, and hence the repositories needs. If the deep-borehole concept of disposing the problematic long-lived radio-nuclides (e.g., ${ }^{129} \mathrm{I},{ }^{99} \mathrm{Tc},{ }^{135} \mathrm{Cs}$, ${ }^{237} \mathrm{~Np}$, etc.), advocated here can be demonstrated to be technically and economically viable, the need for geologic repositories can be significantly minimized.

\section{REFERENCES}

[1] J. S. Choi, "Multi-Sites/Multilateral Controls of Nuclear Fuel Cycle in Asia Pacific," presentation made at the workshop on Multilateral Concepts of Nuclear Fuel Cycle for Asia Pacific at the University of Tokyo, Japan on 2627 October 2009.

[2 ] World Nuclear News, "End of the line for Yucca Mountain," article released on 4 March 2010.

[3 ] First public meeting of the Blue Ribbon Commission of America's Nuclear Future," Willard Intercontinental Hotel, Washington DC, 25-26 March 2010.

[4] Min Lee, "Maintaining Nuclear Power and Dealing with the Spent Fuel - Perspective of Taiwan," presented at the Todai Workshop at the University of Tokyo on 16 March 2009.

[ 5 ] Yongsoo Hwang, "Maintaining Nuclear Power and Dealing with the Spent Fuel in ROK," presented at the Todai Workshop at the University of Tokyo on 16 March 2009.

[6] Tatsujiro Suzuki, "The Role of Japan Atomic Energy Commission in Japan's fuel cycle policy making," presented at the IPFM Workshop in Tokyo on 20 March 2010.

[7] M. Fitzpatrick, "Nuclear Proliferation Challenges," International Institute for Strategic Studies (IISS), lecture given at the University of Tokyo, Japan on 6 June 2008.

[ 8 ] M. Elbaradei, The Economists, 16 October 2003.

[9] The US President Bush's Speech to the National Defense University, 11 February 2004.

[10] On September 5, 2007, Russia's first multilateral nuclear fuel cycle enterprise - the International Uranium Enrichment Center in Angarsk was legally incorporated as a joint venture between Russia's Tekhsnabeksport and Kazakhstan's Kazatomprom.

[11] G. Evans and Y. Kawaguchi, "Eliminating Nuclear Threats, A Practical Agenda for Global Policymakers," Report of the International Commission on Nuclear Non-proliferation and Disarmament, 2009.

[12] "Internationalization of the Nuclear Fuel Cycle, Goals, Strategies, and Challenges," The US National Academy of Sciences and the Russian Academy of Sciences, National Research Council, February 2009.

[13] Pacific Gas \& Electric (PG\&E) received a site-specific license for its Humboldt Bay (HB) NPP from the USNRC in November 2005 that authorized the storage of spent fuel in a unique in-ground concrete structure with storage capacity for six of Holtec's HI-STAR $100 \mathrm{HB}$ systems.

[14] The underground vertical ventilated module (VVM) technology was proposed by Holtec International in 2004 as a robust alternative to above ground casks to store nuclear fuel.

[15] O. K. Earle, "Options for the handling and storage of nuclear vessel spent fuel," NATO Workshop, Moscow, Russia, 22-24 April 2002.

[16] "An international underground twin tunnel concept" HYDRO 2007, New Approaches for a New Era, Granada, Spain, 15-17 October 2007.

[17] A tunnel concept at Neckarwestheim NPP in Germany was developed as a special solution due to the special topographical conditions on-site.

[18] "Operation and Maintenance of Spent Fuel Storage and Transportation Casks/Containers," IAEA-TECDOC-1532, January 2007. 
[19] RSK (Reaktorsicherheitskommission). 2001. Safety-Related Guidelines for the Dry Interim Storage of Spent Fuel Elements in Storage Casks. Recommendation of the Commission on
Reactor Safety. April 5.

[20] "Management and Disposition of Excess Weapons Plutonium," The US National Academies Press, 1994. 